\title{
The caldera-forming eruption of Ksudach volcano about cal. A.D. 240: the greatest explosive event of our era in Kamchatka, Russia
}

\author{
O.A. Braitseva * , I.V. Melekestsev, V.V. Ponomareva, V.Yu. Kirianov \\ Institute of Volcanic Geology and Geochemistry, Petropavlovsk-Kamchatsky, 683006, Russia
}

Received 13 March 1994; accepted 15 June 1995

\begin{abstract}
The largest Plinian eruption of our era and the latest caldera-forming enuption in the Kuril-Kamchatka region occurred about cal. A.D. 240 from the Ksudach volcano. This catastrophic explosive enuption was similar in type and characteristics to the $1883 \mathrm{Krakatau}$ event. The volume of material ejected was $18-19 \mathrm{~km}^{3}\left(8 \mathrm{~km}^{3} \mathrm{DRE}\right)$, including $15 \mathrm{~km}^{3}$ of tephra fall and $3-4 \mathrm{~km}^{3}$ of pyroclastic flows. The estimated height of eruptive column is $22-30 \mathrm{~km}$. A collapse caldera resulting from this eruption was $4 \times 6.5 \mathrm{~km}$ in size with a cavity volume of $6.5-7 \mathrm{~km}^{3}$. Tephra fall was deposited to the north of the volcano and reached more than $1000 \mathrm{~km}$. Pyroclastic flows accompanied by ash-cloud pyroclastic surges extended out to 20 $\mathrm{km}$. The eruption was initially phreatomagmatic and then became rhythmic, with each pulse evolving from pumice falls to pyroclastic flows. Erupted products were dominantly rhyodacite throughout the eruption. During the post-caldera stage, when the Shtyubel cone started to form within the caldera, basaltic-andesite and andesite magma began to effuse. The trigger for the eruption may have been an intrusion of mafic magma into the rhyodacite reservoir. The eruption had substantial environmental impact and may have produced a large acidity peak in the Greenland ice sheet.
\end{abstract}

\section{Introduction}

During the last 10,000 years, five catastrophic explosive caldera-forming eruptions took place in Kamchatka (Table 1): three occurred at the Ksudach volcanic massif and two were associated with the formation of the Karymsky and Kuril Lake-Iliinsky calderas (Braitseva et al., 1992, 1994). Four of these five eruptions occurred during the first half of the Holocene between 9000 and 6000 yr B.P. During the second half of the Holocene only one caldera-forming eruption $\left(\mathrm{KS}_{1}\right)$ took place in Kamchatka, re-

\footnotetext{
${ }^{*}$ Corresponding author.
}

sulting in the collapse of caldera $\mathrm{V}$ at Ksudach volcano about 1800 yr B.P. (Figs. 1 and 2). Its characteristics show that this was the second largest Holocene eruption in Kamchatka, after that associated with the formation of Kuril Lake-Iliinsky caldera, and the greatest explosive event in Kamchatka in our era. It was similar in type and characteristics to the 1883 Krakatau eruption and may have produced a large acidity peak in the Greenland ice sheet. Tephra-fall $\mathrm{KS}_{1}$ covers almost all Kamchatka and is one of the most important marker horizons for the Holocene deposits.

This paper presents the first detailed account of the stratigraphy, age, composition and deposit volume for this eruption. The characteristic features helpful for identification and correlation of $\mathrm{KS}_{1}$ 


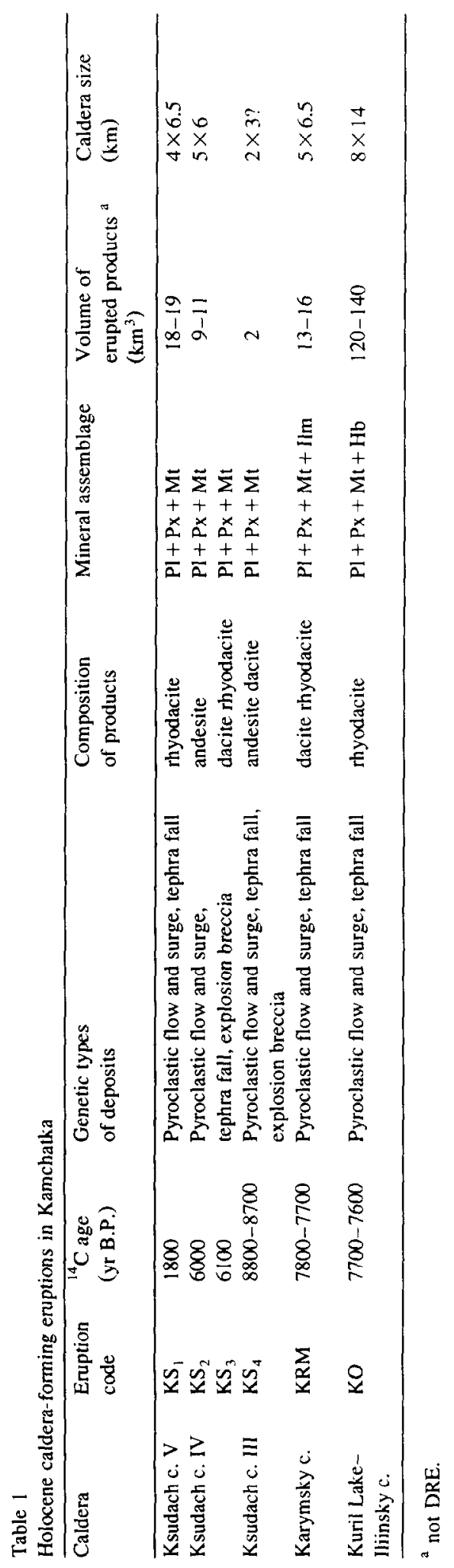




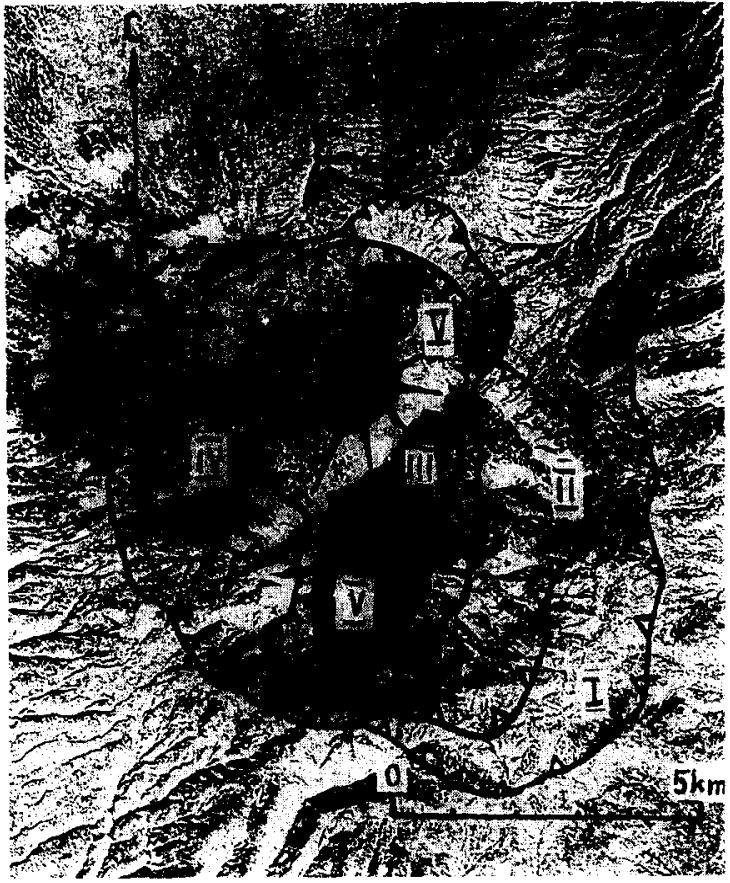

Fig. 1. Calderas of Ksudach volcanic massif. $I$ and $I I$, Late Pleistocene calderas; $I I I, I V$ and $V$, Holocene calderas.

tephra and the area of its dispersion are considered. We reconstruct the course of the eruption and evaluate its environmental impact.

\section{2. $\mathrm{KS}_{1}$ and the eruptive history of Ksudach vol- cano}

Ksudach volcano consists of a shield-like complex surmounted by nested calderas formed during five collapse events (Fig. 1). Two calderas (I and II) formed in the latest Pleistocene times and three (III, IV and V) during the Holocene (Melekestsev and Sulerzhitsky, 1990; Selyangin, 1990). Codes and ages of explosive eruptions associated with the formation of Holocene calderas are from Braitseva et al. (1992, 1994).

Caldera III was formed roughly $8800-8700 \mathrm{yr}$ B.P. The eruption produced pyroclastic flows and tephra fall ( $\mathrm{KS}_{4}$, Fig. 3). The ash fall spread to the southwest. Eruption products were dominantly andesites, with a total volume of about $2 \mathrm{~km}^{3}$.

Caldera IV formed as a result of two nearly coeval eruptions $\mathrm{KS}_{3}$ and $\mathrm{KS}_{2}$ that occurred approxi- mately 6000 and $6100 \mathrm{yr}$ B.P. Both eruptions produced pyroclastic flows and tephra falls. The ash-fall axis of $\mathrm{KS}_{3}$ was directed westward and that of $\mathrm{KS}_{2}$ northward (Braitseva et al., 1992). Pyroclastic deposits of $\mathrm{KS}_{3}$ range from dacite to rhyodacite, but those of $\mathrm{KS}_{2}$ are uniformly andesite. The position of caldera IV, which formed after the $\mathrm{KS}_{3}$ and $\mathrm{KS}_{2}$ eruptions, is shown in Figs. 1 and 4.

The latest caldera-forming (caldera V) eruption, $\mathrm{KS}_{1}$, which is the subject of this study, was separated from the previous caldera-forming eruption $\mathrm{KS}_{2}$ by a 4300 -yr interval. During that interval, at least four eruptions occurred from Ksudach. The three smaller eruptions produced only moderate ashfall deposits, and one large eruption produced about $0.5 \mathrm{~km}^{3}$ of tephra, called the "bomb tuff" (KSbt in Fig. 3), because it contains large bombs of dacitic pumice. That eruption apparently took place about 4500-4000 yr B.P., since its tephra is bracketed stratigraphically between the tephra marker horizons of Khodutka (KHD 2800 yr B.P.) and Zheltovsky (ZLT about 5000 yr B.P.) volcanoes (Fig. 3).

After the caldera $\mathrm{V}$ collapse had taken place, the Shtyubel stratovolcano began to grow within this caldera. All subsequent voluminous eruptions from Ksudach, including the historical one in 1907, originated from the Shtyubel cone.

\section{The $\mathrm{KS}_{1}$ deposits}

The caldera-forming eruption deposits comprise pyroclastic flows, pyroclastic surges and tephra falls.

Pyroclastic-flow deposits fill the river valleys on the northern, western, and eastern slopes of the volcano and form an extensive cover to the north of it. They are also present within older caldera depressions of the central part of the massif (Fig. 4). Deposits include poorly consolidated, white, fine- or coarse-grained tuff with fragments of light-colored pumice. Deposits are commonly non-stratified: sometimes lense-shaped clusters of pumice bombs occur. Non-juvenile material generally makes up only a few percent of the deposits. However, some outcrops have fragments of old lavas and altered rocks constituting as much as $10 \%$ of the total volume.

Four pyroclastic-flow units separated by pumice bomb fall horizons are identified in the valley of the 


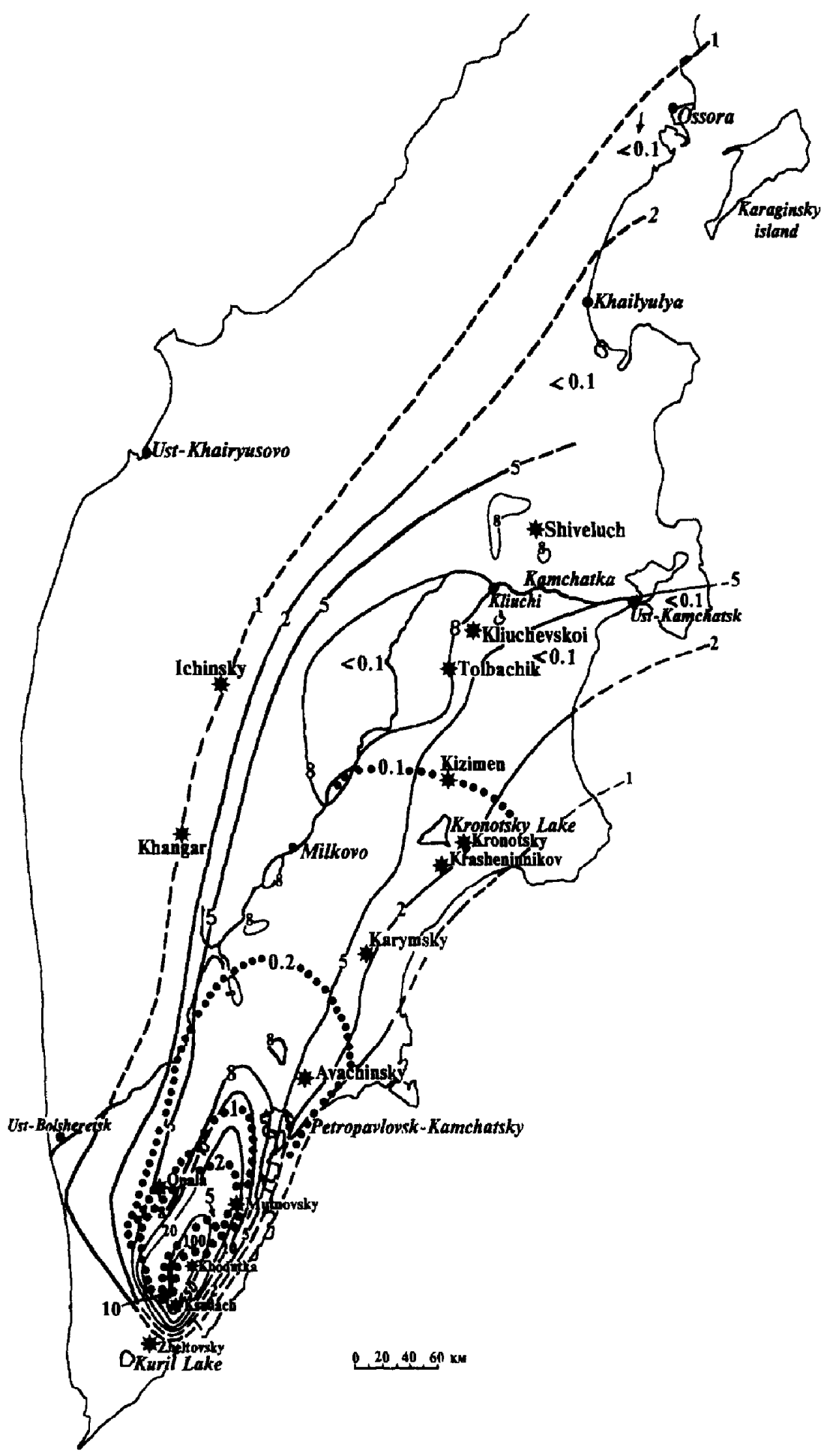

Fig. 2. Isopach $(\mathrm{cm})$ and isopleth (maximum sizes of particles, $\mathrm{cm}$ ) maps for $\mathrm{KS}$, tephra fall. Isopachs, solid and dashed lines; isopleths, large dots. 
Teplaya river (Fig. 3, section 8880). Three lower units comprise white porous pumice and the upper unit consists of grey and blue-grey more dense pumice. Thickness of the units ranges from 4 to 12 $\mathrm{m}$. In the central part of the massif near the caldera rim it locally reaches $30-50 \mathrm{~m}$.

Beyond the area of pyroclastic-flow deposits, related ash-cloud surge deposits ("nuee ardente" deposits) have been identified. In sections at a distance of $20-30 \mathrm{~km}$ from the volcano (Fig. 3, section 8825 ) they replace pyroclastic-flow deposits and have the same stratigraphic position. Ash-cloud surge deposits usually are non-stratified and consist of light-colored fine material with a small admixture of coarse grains. In the region of Khodutka volcano, $30 \mathrm{~km}$ to the northeast, the thickness of such deposits reaches $4-10 \mathrm{~cm}$.

The basal layer of the $\mathrm{KS}_{1}$ sequence near the vent is composed of greenish-grey, dusty consolidated (Fig. 3, section 8880), or stratified coarse-grained material with interlayered fine bands (Fig. 3, section 8839). We interpret this as a pyroclastic base-surge deposit, indicating that the $\mathrm{KS}_{1}$ eruption began with a phreatomagmatic phase, perhaps due to the existence of a lake in former caldera IV.

Proximal tephra falls deposits are pumice lapilli and bombs. At least four bomb beds are identified (Fig. 3, section 8880), each underlying pyroclasticflow deposits. Pumices of the lower three beds are white or yellow and those of the upper bed are grey or blue-grey. Pumice bombs and lapilli reach $40 \mathrm{~cm}$ diameter on the northern part of the caldera rim and $1 \mathrm{~cm}$ at a distance of $145 \mathrm{~km}$ northeast from the vent (Fig. 2).

The ash-fall axis was directed to the north. The grain size diminishes with distance from the volcano (Fig. 2): at sites near Khodutka volcano, $30 \mathrm{~km}$ to the northeast, bombs and lapilli dominate; near Petropavlovsk, $140 \mathrm{~km}$ to the northeast, tephra are lapilli and coarse ash; farther still, near Kizimen volcano, $380 \mathrm{~km}$ to the northeast, the material is coarse and fine ash; beyond $400 \mathrm{~km}$ fine ash dominates. An increase in the fraction of fine $(<0.125$ $\mathrm{mm}$ ) ash with distance is apparent (Figs. 5 and 6).

However, at distal sites more than $400 \mathrm{~km}$ from the vent, the ash is almost entirely composed of accretionary lapilli (Moore and Peck, 1962; Walker and Croasdale, 1972) roughly $0.25 \mathrm{~mm}$ in size, consisting of numerous small $(<63 \mu \mathrm{m})$ glass shards. These accretions present in the $\mathrm{KS}_{1}$ tephra perturb the manner in which the grain size distribution changes with distance, i.e., the increase in a fraction of particles $0.25-0.125 \mathrm{~mm}$ in size due to accretion leads to the bimodal distribution at distances of more than $400 \mathrm{~km}$ (Fig. 5).

The isopach map for the tephra (Fig. 2) shows the distinct secondary increase of ash thickness in the north of the Kamchatka River valley, in the region of the Tolbachik plateau and in the region of Shiveluch volcano. Such a phenomenon was reported by Brazier et al. (1983) for the 1980 Mount St. Helens and 1979 Soufriere eruptions, and is obviously the result of the accretionary lapilli formation.

Pumice particles in the tephra have a delicate appearance. Examination by electron microscope revealed that their principal feature is the great number of thin-walled pores oriented in a random way constituting $>80 \%$ of the particle volume (Fig. 7).

Within castern Kamchatka, the $\mathrm{KS}_{\text {, tephra is a }}$ yellow, coarse to fine ash. In the Kamchatka River valley the tephra comprises two layers: yellow coarse or fine ash below, and grey fine ash at the top. These two layers correspond to two packets of pyroclastics at Ksudach volcano: a lower white or yellow packet and an upper grey one.

\section{The history of identification and correlation of $\mathrm{KS}_{1}$ tephra}

$\mathrm{KS}_{1}$ tephra is one of the most important regional marker horizons for Holocene stratigraphy because it covers almost all Kamchatka. We shall discuss the history of identification and correlation of $\mathrm{KS}_{1}$ tephra within the peninsula since in earlier publications it was given a variety of names attributed to a variety of eruptive centers.

Previously the $\mathrm{KS}_{1}$ ash in the region of the Kliuchevskoi volcano group and Kliuchi city was described as ash from Shiveluch volcano and designated $\mathrm{SH}_{4}$ (Piyp, 1948; Menyailov, 1955; Markhinin et al., 1962; Gushchenko, 1965; Dikov, 1969; Braitseva et al., 1984, 1988, 1989b, 1991). This fine ash served as an important marker horizon and was used in tephrochronological studies at Tolbachik, Kliuchevskoi, and Bezymianny volcanoes and during 
archaeological investigations in the Kamchatka River valley. However, studies of the chemical and mineral compositions of the ash demonstrated that it differed from other ashes of Shiveluch volcano (Geptner and
Ponomareva, 1979; Kirianov, 1983; Felitsyn and Kirianov, 1990; Felitsyn et al., 1991). The ash does not contain hornblende, which is common at Shiveluch, has a low $\mathrm{K}_{2} \mathrm{O}$ content, and consists nearly

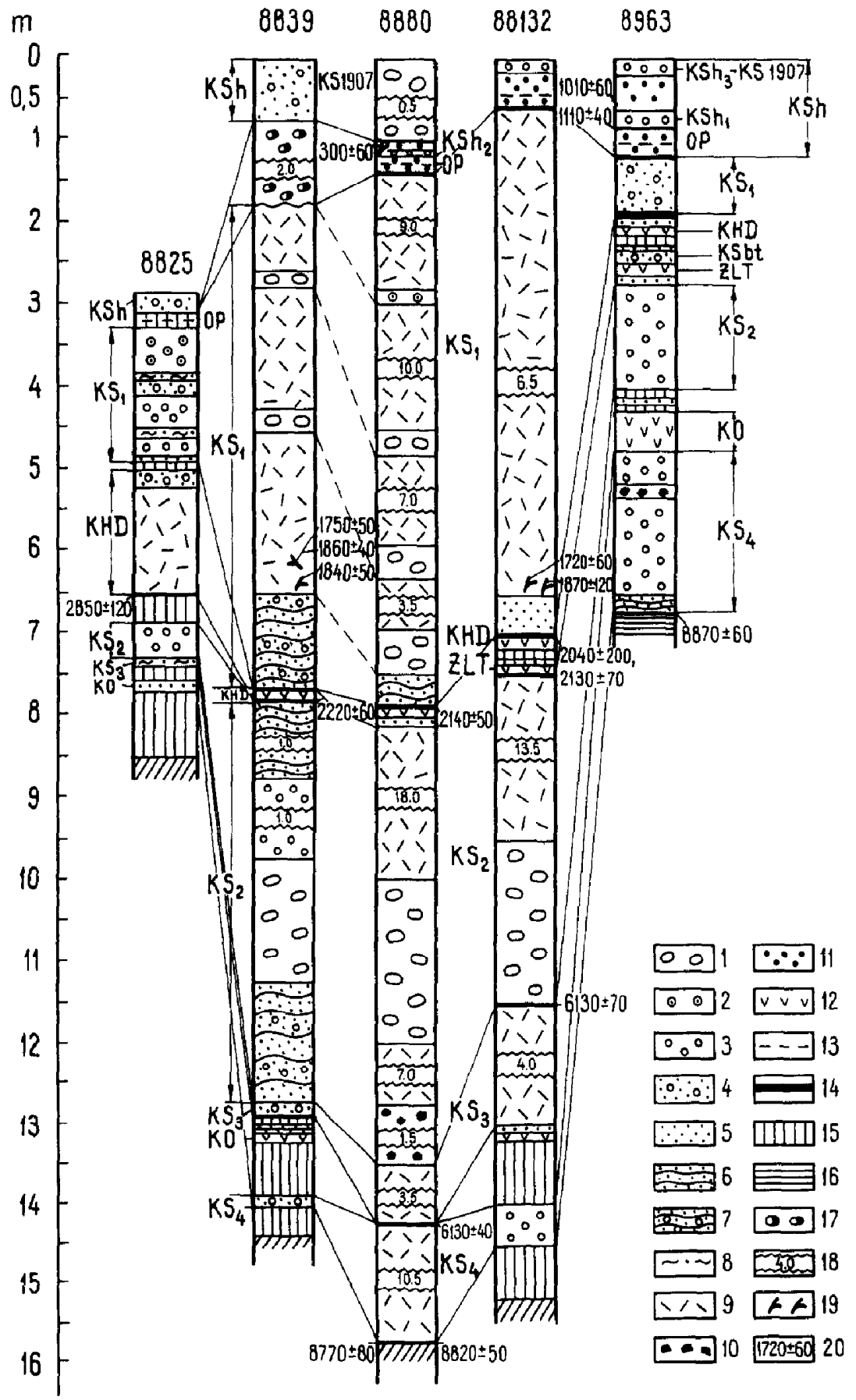


entirely of volcanic glass, which suggests a distant source. Later we obtained new data confirming that neither the grain size nor thickness of this ash increased toward Shiveluch.

During tephrochronological studies in southern and eastern Kamchatka, a tephra horizon KHD was recognized and attributed at the time to Khodutka volcano (Fig. 2), for its thickness (2-4 m) and clast size (bombs up to $10-15 \mathrm{~cm}$ ) were very large there (Kirsanova and Melekestsev, 1988; Melekestsev and Kirianov, 1988; Braitseva et al., 1989a; Melekestsev et al., 1990). Its thickness gradually decreases to the north of Khodutka volcano. In the region of Kronotsky lake and Kizimen volcano, the coarse ash from this horizon was seen to lie directly above the fine ash $\mathrm{SH}_{4}$. The composition of ash $\mathrm{SH}_{4}$ was found to be similar to that of KHD (Kirianov et al., 1990). Later tracing and correlation of ashes in southern Kamchatka let us see that ash KHD was produced by the Ksudach caldera-forming eruption ( $\mathrm{KS}_{1}$ ) because its thickness and clast sizes increase towards a maximum at this volcano. We studied the $\mathrm{KS}_{1}$ erupted products near Ksudach and obtained new data on their composition and ages.

At the same time, in the valley of the Kamchatka River, we identified a fine grey ash that lies directly above layers $\mathrm{KHD}$ and $\mathrm{SH}_{4}$ and whose composition was similar to that of these ashes. Its source remained unknown.

Ultimately we reinterpreted all the evidence accumulated, using data from direct tracing of ashes, their composition and their ages. Based on these data, we concluded that all of the described ash beds - KHD, $\mathrm{SH}_{4}$ and the grey ash in the Kamchatka River valley-are products of the same Ksudach caldera-forming eruption $\mathrm{KS}_{1}$. The ash exhibits regular decreasing grain size with distance from the source, from the proximal coarse tephra "KHD" to the distal fine ash " $\mathrm{SH}_{4}$ ". The progressive decrease of tephra thickness is somewhat complicated by its secondary thickening in the region of the Kliuchevskoi volcano group. The composition of all the tephra corresponds universally to that of pyroclastics from Ksudach volcano. The position of grey ash in the upper tephra horizon in the Kamchatka River valley is consistent with the stratigraphic position of the grey pumice deposits in the upper part of the sequence at Ksudach volcano. Grey ash was not found within eastern Kamchatka, which is interpreted to result from a shift of ash dispersal axes for "yellow" and "grey" tephra.

\section{Composition of products}

The major component of $\mathrm{KS}_{1}$ tephra is volcanic glass. It dominates in lapilli and bombs (97\%) and in fine ash $(93 \%)$. In coarse ash the volcanic glass content decreases to $80-85 \%$ because of increasing crystal content (Fig. 8) due to eolian differentiation. The mineral assemblage of erupted products comprises plagioclase, ortho- and clinopyroxene, and titanomagnetite. Hornblende is lacking.

Bombs and lapilli near the vent are low-potassium rhyodacites (Fig. 9). Their composition remained constant during the $\mathrm{KS}_{1}$ enuption (Fig. 10). Both white and grey pumice bombs and lapilli at Ksudach and yellow and grey fine ash at distal localities do not differ in composition (Table 2) and contain from 68 to nearly $72 \% \mathrm{SiO}_{2}$. Coarse ash, which fell at

Fig. 3. Position of $\mathrm{KS}_{1}$ deposits in a pyroclastic sequence of Ksudach volcano. Tephra $(I-5): l=$ bombs and lapilli of white to yellow pumice; $2=$ bombs and lapilli of blue-grey pumice in the $\mathrm{KS}$, pyroclastics; $3=$ lapilli; $4=$ coarse ash and lapilli; $5=$ coarse ash. Pyroclastic surge deposits $(6-8): 6=$ stratified coarse ash; $7-$ stratificd coarsc ash with lapilli; $8=$ fine ash of pyroclastic surges from ash clouds; $9=$ pyroclastic-flow deposits; $10=$ explosion breccia; $11=$ pyroclastics from Shtyubel cone; $12=$ tephra from other volcanoes; $13=$ marker tephra layer from Opala volcano (not to scale); $14=$ buried soils; $15=$ sandy loams; $16=$ lacustrine deposits; $17=$ lahar deposits; $18=$ discontinuity of layer thickness in meters; $19=$ wood and charcoal; $20=$ radiocarbon dates. $K S_{I}, K S_{2}, K S_{3}, K S_{4}$, deposits of caldera-forming eruptions from Ksudach volcano. $K S b t=$ "bomb tuff" from Ksudach volcano. $K S h=$ pyroclastics from Shtyubel cone; $K S h_{f}, K S h_{2}, K S h_{3}=$ tephra from the largest eruptions from Shtyubel cone. Tephra marker beds: $O P$, from Opala volcano (Baraniy Amphitheater) 1500-1400 yr B.P.; KHD, from Khodutka volcano (Khodutkinsky “'maar") 2800 yr B.P.; ZLT, from Zheltovsky volcano 5000 yr B.P.; $K O$, eruptions associated with formation of Kuril Lake-Iliinsky caldera (7700-7600 yr B.P.). Sections locations are shown in Fig. 4. Section 8825 is located at Khodutka volcano $30 \mathrm{~km}$ north of Ksudach volcano. 

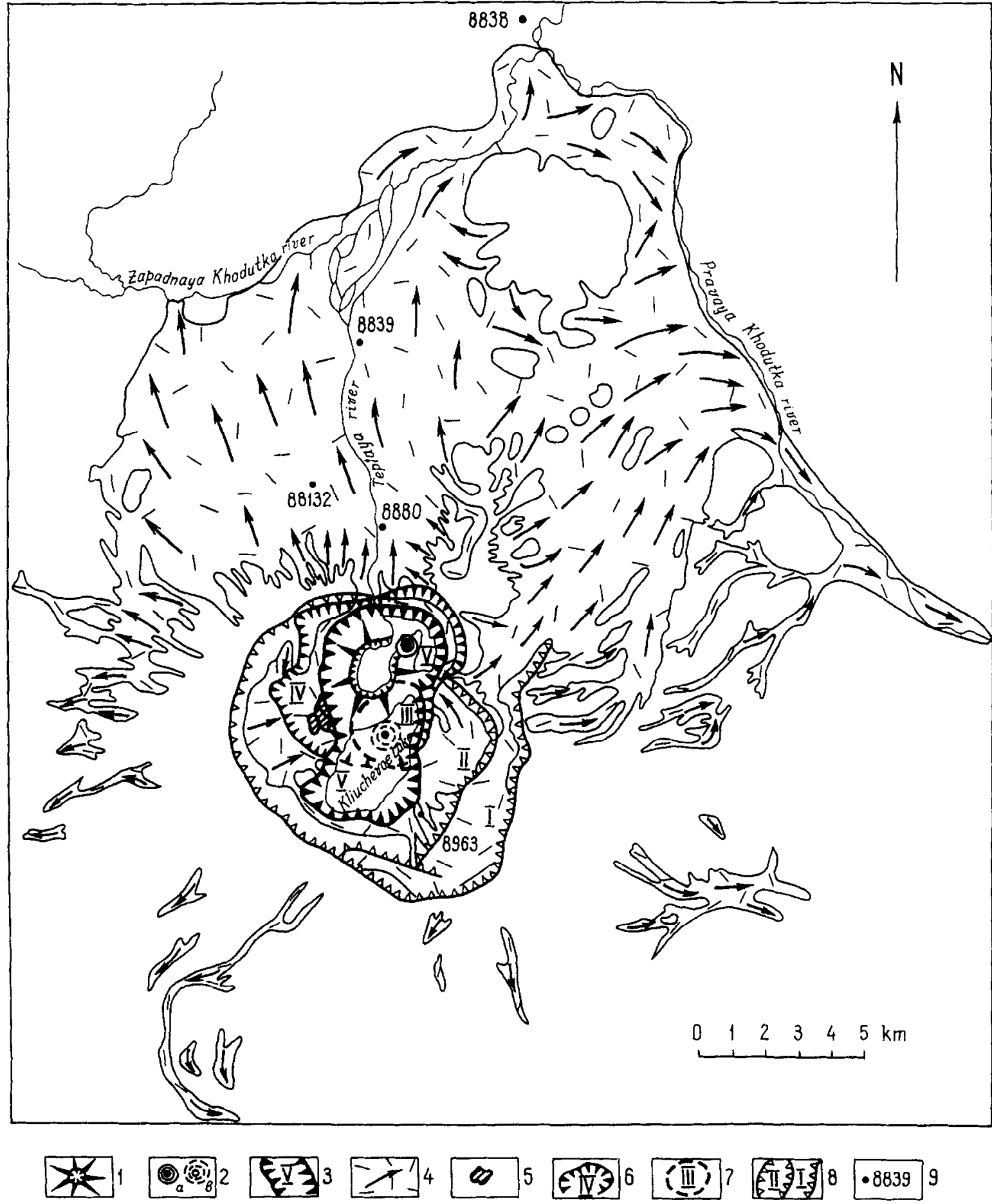

Fig. 4. Pyroclastic flows $\mathrm{KS}_{1}$ and position of caldera V. $l=$ Shtyubel cone and its crater; 2 = post-caldera extrusive domes in caldera $\mathrm{V}$, $a$ established, $b$ presumed; $3=$ caldera $V$ scarp; $4=\mathrm{KS}_{1}$ pyroclastic flows; $5=$ post-caldera extrusive domes (Paryashchiy Utes, etc.) in caldera $I V ; 6=$ caldera $I V$ scarp; $7=$ presumed position of caldera $I I I ; 8=$ scarp edges of Late Pleistocene calderas $I$ and $I I ; 9=$ numbers of sections shown in Fig. 3. 8639 and 8839 are the numbers of the same section measured twice. 

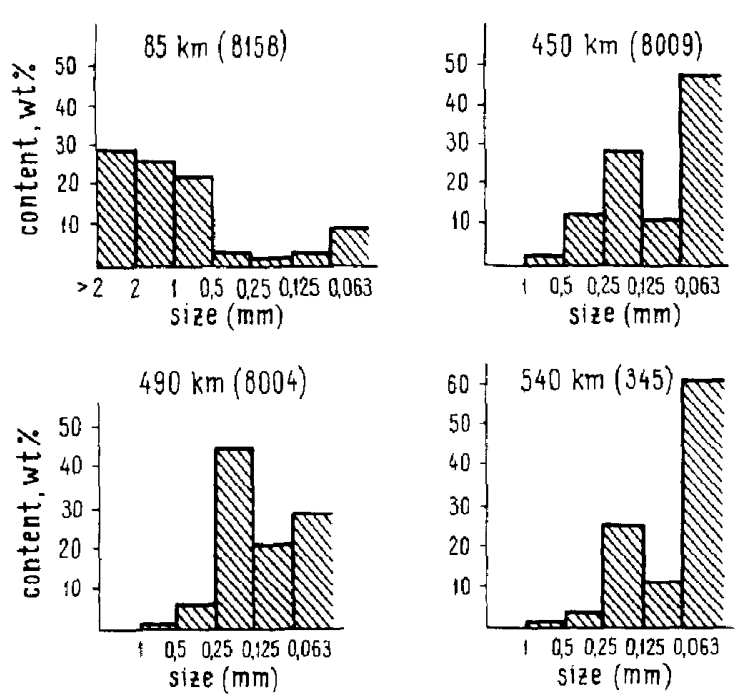

Fig. 5. Histograms of grain size distribution for $\mathrm{KS}_{1}$ tephra at different distances from the eruptive center. Numbers of sections are bracketed. For sections locations see Fig. 6.

some distance from the volcano (Figs. 2 and 9), is more mafic and contains from 63 to $68 \% \mathrm{SiO}_{2}$ as a result of its enrichment in minerals due to eolian differentiation (Fig. 8). The most distal ash sample, in Ossora village at $900 \mathrm{~km}$ distance, has the highest $\mathrm{SiO}_{2}$ content, $73.72 \%$; this sample consists nearly entirely of volcanic glass. Thus, lateral variations in composition of $\mathrm{KS}_{1}$ ash related to eolian gravitational differentiation are compatible with regular

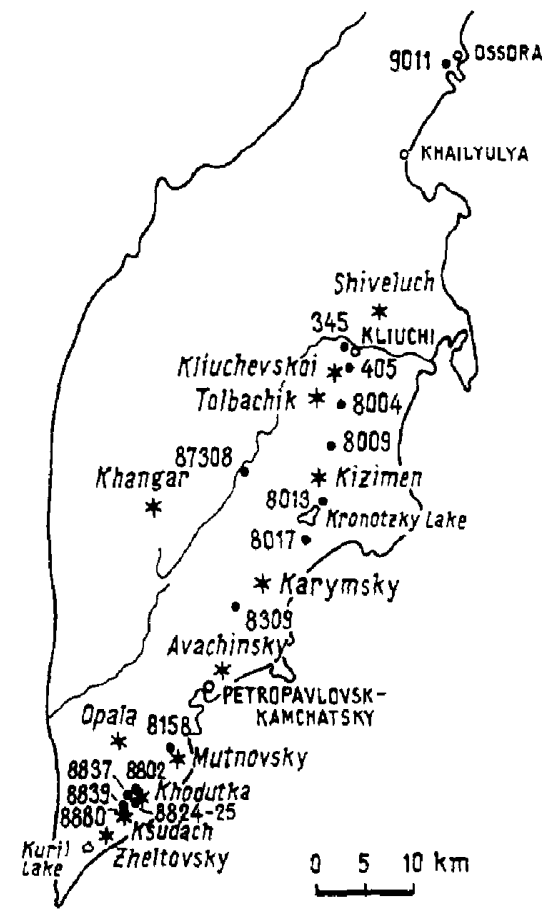

Fig. 6. Locations of sections for which grain size (Fig. 5), chemical (Table 2) and mineral (Fig. 8) compositions of $\mathrm{KS}_{1}$ pyroclastics are given. 8639 and 8839 are the numbers of the same section measured twice.

trends obtained for other Kamchatkan ashes (Kirianov and Solovyova, 1991). Notwithstanding the fact that $\mathrm{SiO}_{2}$ contents of ashes range by $11 \%$, all the sam-

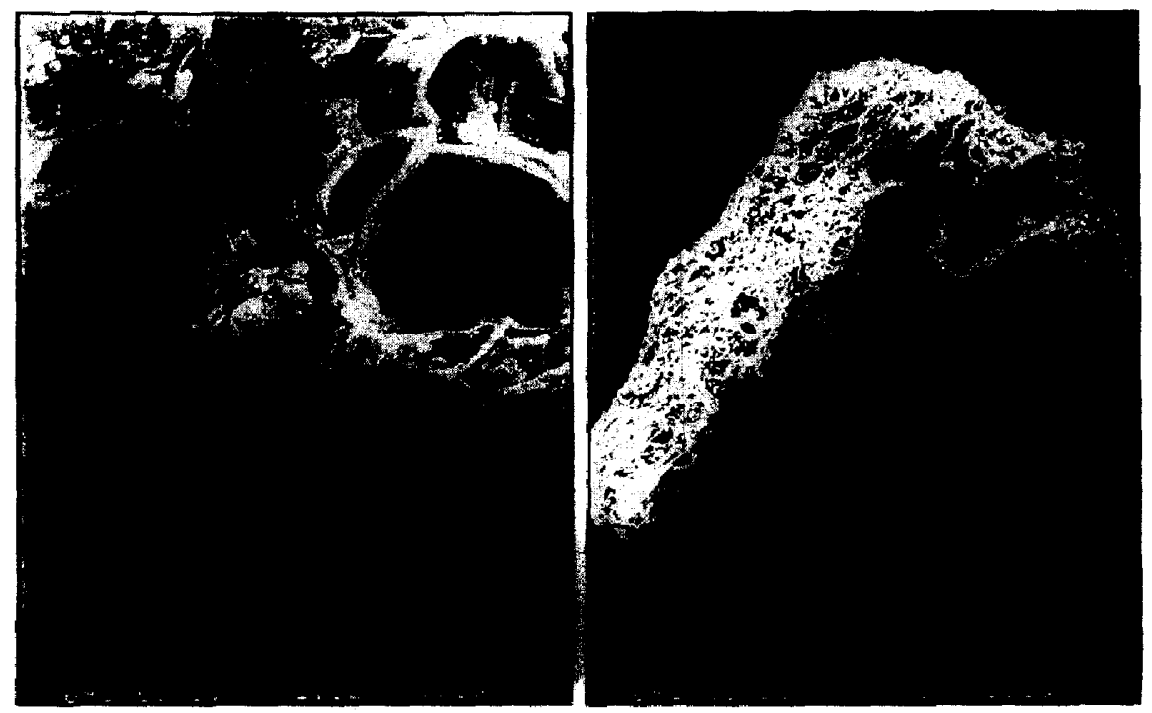

Fig. 7. Surface of a pumice particle from $\mathrm{KS}_{1}$ tephra under scanning electron microscope. Left $\times 2020$; right $\times 130$. 


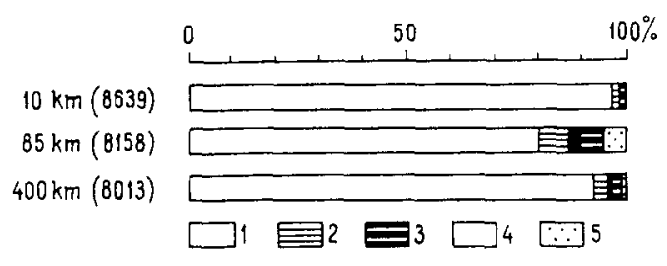

Fig. 8. Mineral composition of $\mathrm{KS}_{1}$ tephra-fall deposits at different distances from the eruptive center: $10 \mathrm{~km}$-lapilli and bombs; $85 \mathrm{~km}-$ dominantly coarse ash; $400 \mathrm{~km}$-dominantly fine ash. $1=$ volcanic glass; 2 = plagioclase; $3=$ rock fragments and altered minerals; $4=$ magnetite; $5=$ pyroxenes. Numbers of sections are bracketed.

ples fall into the field of low-potassium rocks, forming a swarm of points parallel to its upper boundary defined by Gill (1981) (Fig. 9).

Studies of the composition of $\mathrm{KS}_{1}$ tephra throughout Kamchatka made it possible to determine its characteristic features helpful for identification and correlation of this excellent marker horizon. These features are: (1) $\mathrm{SiO}_{2}$ contents $63-74 \%$; (2) low potassium content; and (3) lack of hornblende. These criteria combined with data on ages are sufficient to discriminate $\mathrm{KS}_{1}$ tephra from Shiveluch, Opala and Khodutka ashes that are close to $\mathrm{KS}_{1}$ tephra strati-

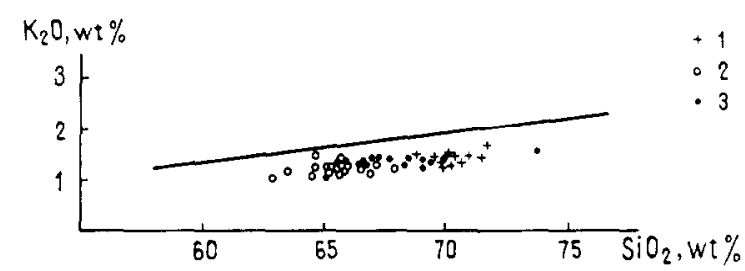

Fig. 9. Classification diagram for $\mathrm{KS}_{\text {, }}$ pyroclastic deposits. Upper boundary of the field of low-K rocks after Gill (1981). l= bombs and pumice lapilli; $2=$ dominantly coarse ash; $3=$ dominantly fine ash.

graphically and in $\mathrm{SiO}_{2}$ abundance (Braitseva et al., 1992, 1994).

\section{The collapse caldera}

Collapse caldera V formed as a result of the $\mathrm{KS}_{1}$ eruption (Figs. 1 and 4). Its boundaries are defined

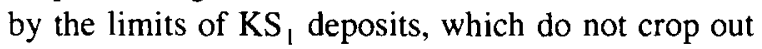
inside the caldera. The southern part of the caldera coincides with caldera III-1 recognized by Selyangin (1990). However, we regard it as including also the

Table 2

Representative analyses of products from the Ksudach eruption $\mathrm{KS}_{1}$

\begin{tabular}{|c|c|c|c|c|c|c|c|c|c|}
\hline \multirow{3}{*}{$\begin{array}{l}\text { Cumpo- } \\
\text { nents }\end{array}$} & \multicolumn{3}{|c|}{ Bombs and pumice lapilli } & \multicolumn{3}{|c|}{ Coarse ash } & \multicolumn{3}{|l|}{ Fine ash } \\
\hline & \multicolumn{2}{|c|}{$\begin{array}{l}\text { White, yellow from } \\
\text { lower unit }\end{array}$} & \multirow{2}{*}{$\begin{array}{l}\text { Grey from } \\
\text { upper unit } \\
8802 / 2\end{array}$} & \multirow[b]{2}{*}{$8824 / 2$} & \multirow[b]{2}{*}{$8309 / 3$} & \multirow[b]{2}{*}{$8017 / 1$} & \multicolumn{2}{|c|}{ Pale-yellow } & \multirow{2}{*}{$\begin{array}{l}\text { Grey } \\
- \\
87308 / 2\end{array}$} \\
\hline & $8880 / 5$ & $8637 / 15$ & & & & & $405 / 15$ & $9011 / 2$ & \\
\hline $\mathrm{SiO}_{2}$ & 71.78 & 69.73 & 70.09 & 62.86 & 65.20 & 67.90 & 68.34 & 73.72 & 69.89 \\
\hline $\mathrm{TiO}_{2}$ & 0.55 & 0.67 & 0.59 & 1.06 & 0.76 & 0.62 & 0.48 & 0.69 & 0.61 \\
\hline $\mathrm{Al}_{2} \mathrm{O}_{3}$ & 14.68 & 14.98 & 15.08 & 15.03 & 17.24 & 16.04 & 15.77 & 14.60 & 14.67 \\
\hline $\mathrm{Fe}_{2} \mathrm{O}_{3}$ & 0.59 & 1.67 & 0.55 & 3.00 & 1.78 & 0.87 & 1.70 & $2.87^{\mathrm{a}}$ & 1.12 \\
\hline $\mathrm{FeO}$ & 2.53 & 2.72 & 3.24 & 5.43 & 3.88 & 3.59 & 2.65 & - & 2.69 \\
\hline $\mathrm{MnO}$ & 0.14 & 0.09 & 0.15 & 0.14 & 0.18 & 0.14 & 0.14 & 0.08 & 0.15 \\
\hline $\mathrm{MgO}$ & 0.87 & 0.44 & 1.11 & 1.88 & 1.51 & 1.40 & 1.35 & 0.54 & 1.07 \\
\hline $\mathrm{CaO}$ & 2.29 & 3.35 & 2.87 & 5.79 & 4.20 & 3.42 & 3.82 & 1.09 & 3.92 \\
\hline $\mathrm{Na}_{2} \mathrm{O}$ & 4.91 & 4.83 & 4.82 & 3.58 & 3.85 & 4.60 & 4.31 & 4.67 & 4.36 \\
\hline $\mathrm{K}_{2} \mathrm{O}$ & 1.57 & 1.42 & 1.41 & 1.05 & 1.15 & 1.23 & 1.32 & 1.52 & 1.38 \\
\hline $\mathrm{P}_{2} \mathrm{O}_{5}$ & 0.10 & 0.09 & 0.10 & 0.17 & 0.26 & 0.18 & 0.12 & 0.22 & 0.14 \\
\hline L.O.I. & 5.08 & 1.82 & 4.27 & 8.01 & 6.85 & 6.40 & 4.00 & 46.25 & 2.73 \\
\hline Total & 99.56 & 100.34 & 99.58 & 99.68 & 99.74 & 99.75 & 99.55 & 99.55 & 100.10 \\
\hline
\end{tabular}

Analyses were made at the Chemical Laboratory of the Institute of Volcanology by "wet" chemical method. Analyses were recalculated water and organic matter free. L.O.l.(loss on ignition) and original analytical totals are listed under the line.

total $\mathrm{FeO}$ as $\mathrm{Fe}_{2} \mathrm{O}_{3}$. 
area where the Shtyubel cone is presently located. Earlier Melekestsev (Melekestsev and Sulerzhitsky, 1990) described only this northern part as caldera V. In this area, particularly to the north and east, caldera $\mathrm{V}$ corresponds closely in position with caldera IV, which surrounds it. The boundary of caldera $\mathrm{V}$ is defined by scarps west and east of the lake, and in the southwest its scarp bounds the Paryashchiy Utes (Steaming Rock) extrusion. This scarp cannot belong to caldera IV for the following reasons.

Tephrochronological studies have shown that the volcanic massif, consisting of a series of extrusions -including Paryashchiy Utes (Fig. 4) - is not of Late Pleistocene age, as was previously considered, but is substantially younger. Lavas of this massif are overlain only by $\mathrm{KS}_{1}$ pyroclastics; no other more ancient pyroclastics, including $\mathrm{KS}_{2}$ and $\mathrm{KS}_{3}$ are present on them. Consequently, these extrusions formed after the $\mathrm{KS}_{2}$ eruption and formation of caldera IV. They are somewhat younger than $6000 \mathrm{yr}$ B.P., and this is the reason why the Paryashchiy Utes retains heat and is actively steaming. Thus, this massif is interpreted to be a series of post-caldera extrusions within caldera IV. Then the pronounced scarp bounding the Paryashchiy Utes is part of the caldera V boundary (Fig. 4).

The caldera is $4 \times 6.5 \mathrm{~km}$ in diameter and has an area of $19 \mathrm{~km}^{2}$ within the rim; it is $4 \times 5.5 \mathrm{~km}$ and

Table 3

Radiocarbon dates for eruption deposits $\mathrm{KS}_{1}$

\begin{tabular}{|c|c|c|c|}
\hline Date & Sample No. & Area of sampling & Material for dating \\
\hline $1720 \pm 60^{*}$ & GIN-2959a & Ksudach volcano & charcoal $^{\mathrm{a}}$ \\
\hline $1750 \pm 5 * 0$ & GIN-2975a & Ksudach volcano & wood $^{2}$ \\
\hline $1840 \pm 50^{*}$ & GIN-2974 & Ksudach volcano & charcoal $^{a}$ \\
\hline $1860 \pm 40^{*}$ & GIN-2975b & Ksudach volcano & wood $^{a}$ \\
\hline $1870 \pm 120^{*}$ & GIN-2959b & Ksudach volcano & charcoal $^{2}$ \\
\hline $1690 \pm 80^{*}$ & GIN-6321 & Yar Chemy, Kamchatka River & peat over ash $K S_{1}$ \\
\hline $1780 \pm 40^{*}$ & IVAN-191 & Karymsky volcano & soil over ash $\mathrm{KS}_{1}$ \\
\hline $1800 \pm 200^{*}$ & IVAN-328 & Uzon caldera & soil over ash $\mathrm{KS}_{\mathrm{I}}$ \\
\hline $1660 \pm 70^{*}$ & IVAN-397 & Petropavlovsk-Kamchatsky city & peat under ash $\mathrm{KS}_{\text {। }}$ \\
\hline $1690 \pm 190^{*}$ & IVAN-705 & Sharomy village & peat under ash $\mathrm{KS}_{1}$ \\
\hline $1820 \pm 120^{*}$ & IVAN -450 & Yar Cherny & peat under ash $\mathrm{KS}_{1}$ \\
\hline $1860 \pm 40^{*}$ & IVAN-193 & Karymsky volcano & soil under ash $\mathrm{KS}_{1}$ \\
\hline $1860 \pm 60^{*}$ & GIN-1356 & Valley of Paratunka River & soil under ash $\mathrm{KS}_{1}$ \\
\hline $1860 \pm 150^{*}$ & IVAN-331 & Uzon caldera & soil under ash $\mathrm{KS}_{1}$ \\
\hline $1890 \pm 80^{*}$ & IVAN-639 & Avachinsky volcano & peat under ash $\mathrm{KS}_{1}$ \\
\hline $1920 \pm 50$ & GIN-2991 & Khodutka volcano & peat under ash $\mathrm{KS}_{\mathrm{l}}$ \\
\hline $1950 \pm 60$ & IVAN-556 & Yar Chemy & soil under ash $\mathrm{KS}_{1}$ \\
\hline $2050 \pm 50$ & GIN-1180 & Petropavlovsk-Kamchatsky city & peat under ash $\mathrm{KS}_{\mathrm{I}}$ \\
\hline $2040 \pm 200$ & GIN-2980 & Ksudach volcano & soil under pyroclastic-flow deposits \\
\hline $2130 \pm 70$ & GIN-2959 & Ksudach volcano & soil under pyroclastic-flow deposits \\
\hline $2140 \pm 50$ & GIN-2985 & Ksudach volcano & soil under pyroclastic-flow deposits \\
\hline $2220 \pm 60$ & GIN-2976 & Ksudach volcano & soil under pyroclastic-flow deposits \\
\hline $2200 \pm 90$ & GIN-1853 & Karymsky volcano & soil under ash $K S_{1}$ \\
\hline $2020 \pm 90$ & IVAN-70 & Tolbachik plateau & soil under ash $\mathrm{KS}_{1}$ \\
\hline $2240 \pm 40$ & IVAN-36 & Tolbachik platcau & wood from soil over ash $\mathrm{KS}_{\text {। }}$ \\
\hline $2060 \pm 50$ & GIN-1852 & Tolbachik plateau & charcoal in soil under ash $\mathrm{KS}_{1}$ \\
\hline $2070 \pm 120$ & IVAN-57 & Tolbachik plateau & charcoal in soil under ash $\mathrm{KS}_{\mathrm{I}}$ \\
\hline $2440 \pm 50$ & IVAN-82 & Tolbachik plateau & soil under ash $\mathrm{KS}_{1}$ \\
\hline $2460 \pm 100$ & IVAN-55 & Tolbachik plateau & soil under ash $\mathrm{KS}_{1}$ \\
\hline $2080 \pm 100$ & IVAN-132 & Kliuchevskoi volcano & soil under ash $K S_{1}$ \\
\hline $2040 \pm 80$ & IVAN-121 & Kliuchevskoi volcano & charcoal in soil under ash $\mathrm{KS}_{1}$ \\
\hline
\end{tabular}

The table contains all the dates on charcoal and wood, but for the soils and peat only the values of the oldest extracts from the layers overlying the ash horizon and those of the youngest extracts from underlying layers (see Fig. 11), since they define the age of ash. The dates used for the calculation of the average age are marked with an asterisk.

${ }^{a}$ Material from pyroclastic-flow deposits. 

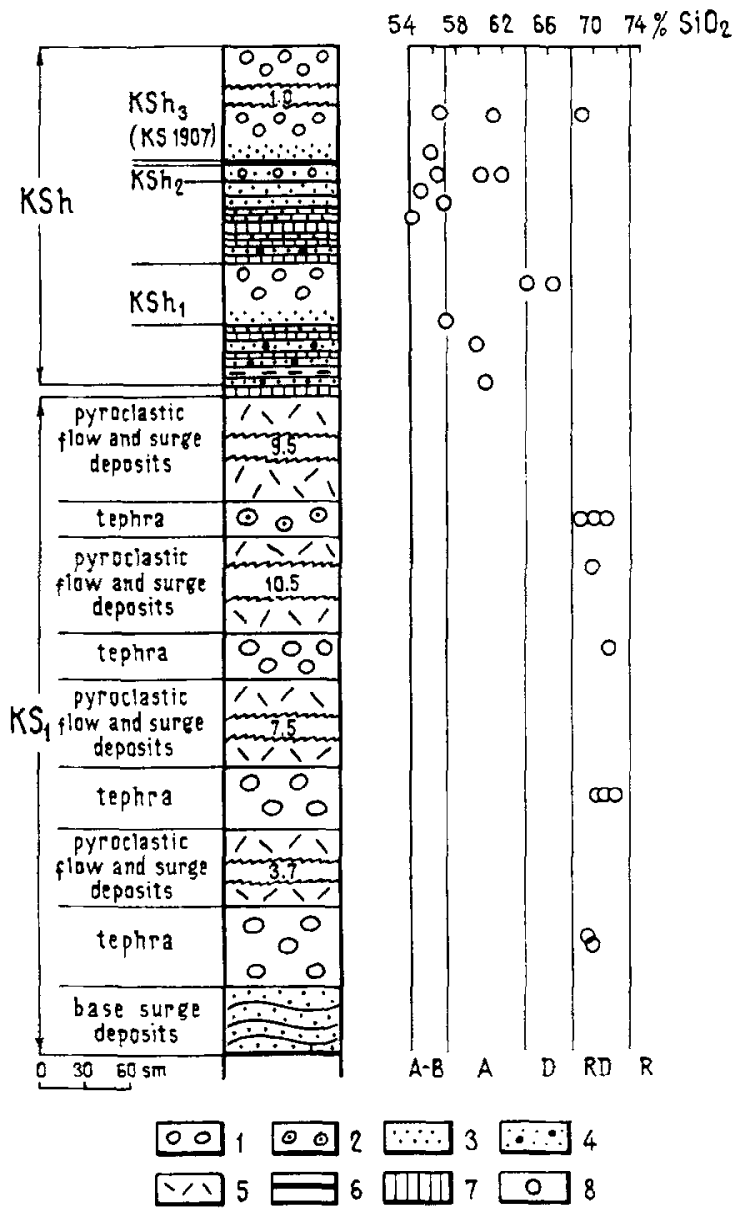

Fig. 10. Deposit sequence for eruption $\mathrm{KS}_{1}$ and formation of Shtyubel cone. $I=$ bombs and lapilli of light-colored pumice; $2=$ lapilli of blue-grey pumice; $3=$ coarse ash; $4=$ coarse ash with lapilli; $5=$ pyroclastic-flow and -surge deposits; $6=$ buried soil horizons; $7=$ sandy loams; $8=\mathrm{SiO}_{2}$ content of pyroclastic material. For other symbols see Fig. 3 .

$15 \mathrm{~km}^{2}$ in area at the bottom. The volume of its cavity down to lakes Kliuchevoe and Shtyubel is about $4.5 \mathrm{~km}^{3}$, and if we take into account the volumes of the lakes and post-collapse volcanic fill the original volume of the caldera cavity may be $6.5-7 \mathrm{~km}^{3}$.

\section{The age}

At present about $30{ }^{14} \mathrm{C}$ dates are available for $\mathrm{KS}_{1}$ deposits at the volcano and at different distances from it (Table 3; Fig. 11). Dates ranging from 1870 to 1720 yr B.P. have been obtained on charcoal and wood in pyroclastic-flow deposits near the caldera. Dates obtained on the soil and peat underlying the $\mathrm{KS}_{1}$ tephra range from 2400 to $1660 \mathrm{yr}$ B.P. The younger of them (1890-1660 yr B.P.) are in good agreement with the above-mentioned dates on charcoal and wood. The soils below $\mathrm{KS}_{1}$ tephra (sections 1,4 and 6 in Fig. 11) that give older ages (2200-2000 yr B.P.), must have been formed over a long period of time, with the dates obtained reflecting the mean age of the whole soil horizon. Dates ranging from 1800 to 1690 yr B.P. on the soil and peat overlying $\mathrm{KS}_{1}$ tephra (Fig. 11) also indicate that the cruption took place at $1800-1700 \mathrm{yr}$ B.P.

We note that dates in sections 8 and 9 differ somewhat. Dates of about 2000 yr B.P. and older have been obtained here on soils not only underlying the ash, but also overlying it, as well as on charcoals and wood. At the Kliuchevskoi volcano group the age of this ash, called previously $\mathrm{SH}_{4}$, was determined to be roughly 2000 yr B.P. (Braitseva et al., 1988). However, outside the Kliuchevskoi volcano group farther northeast we again obtain dates of 1800-1700 yr B.P. for the same ash (section 10). The older ages of the charcoal and wood could be explained by old wood trees that died a few hundred years before the eruption. The reason for the older ages of the soils overlying the ash in the region of the Kliuchevskoi volcano group remains obscure.

We determined the weighted average age and calendric age of the $\mathrm{KS}_{1}$ eruption from the technique of Stuiver and Reimer (1993). For the calculations we used the dates on charcoal, wood, and thin soil and peat layers. Dates from thick soil layers were used only in cases where data were obtained on successive alkaline extracts (technique of Sulerzhitsky, see Braitseva et al., 1993), in which case we used the younger dates for the soil underlying and the older dates for the soil overlying the tephra. The dates used in the calculation are starred in Table 3. The weighted average radiocarbon age calculated from these fifteen dates is $1806 \pm 16 \mathrm{yr}$ B.P. that corresponds to calibrated age A.D. 147(236)317 $( \pm 2 \sigma)$.

\section{The volume of erupted products}

The $\mathrm{KS}_{1}$ eruption produced the greatest volume of erupted material (Table 1) of all the caldera-forming 
eruptions from Ksudach. Tephra-fall deposits dominated the eruption products.

The contours and the area of the ash-fall zone, and consequently, the fall deposit volume, cannot be defined precisely because great amounts of ash fell over the sea. Even on land it is difficult to reconstruct the boundaries of the ash-fall zone outside the $1-\mathrm{cm}$ isopach, because no distinctive tephra layers were preserved there. Based on the isopach map
(Fig. 2) the area and the volume of tephra-fall deposits inside the $1-\mathrm{cm}$ isopach may be roughly estimated to be $300,000 \mathrm{~km}^{2}$ and $13 \mathrm{~km}^{3}$, respectively. By analogy with a smaller (tephra volume 1.5-2 $\mathrm{km}^{3}$ ), but similar Plinian eruption of Ksudach in 1907, when the ash fell over an area of about $1,000,000 \mathrm{~km}^{2}$, one may propose that the area of ash fall during the $\mathrm{KS}_{1}$ caldera-forming eruption was a few millions of square kilometers as estimated for

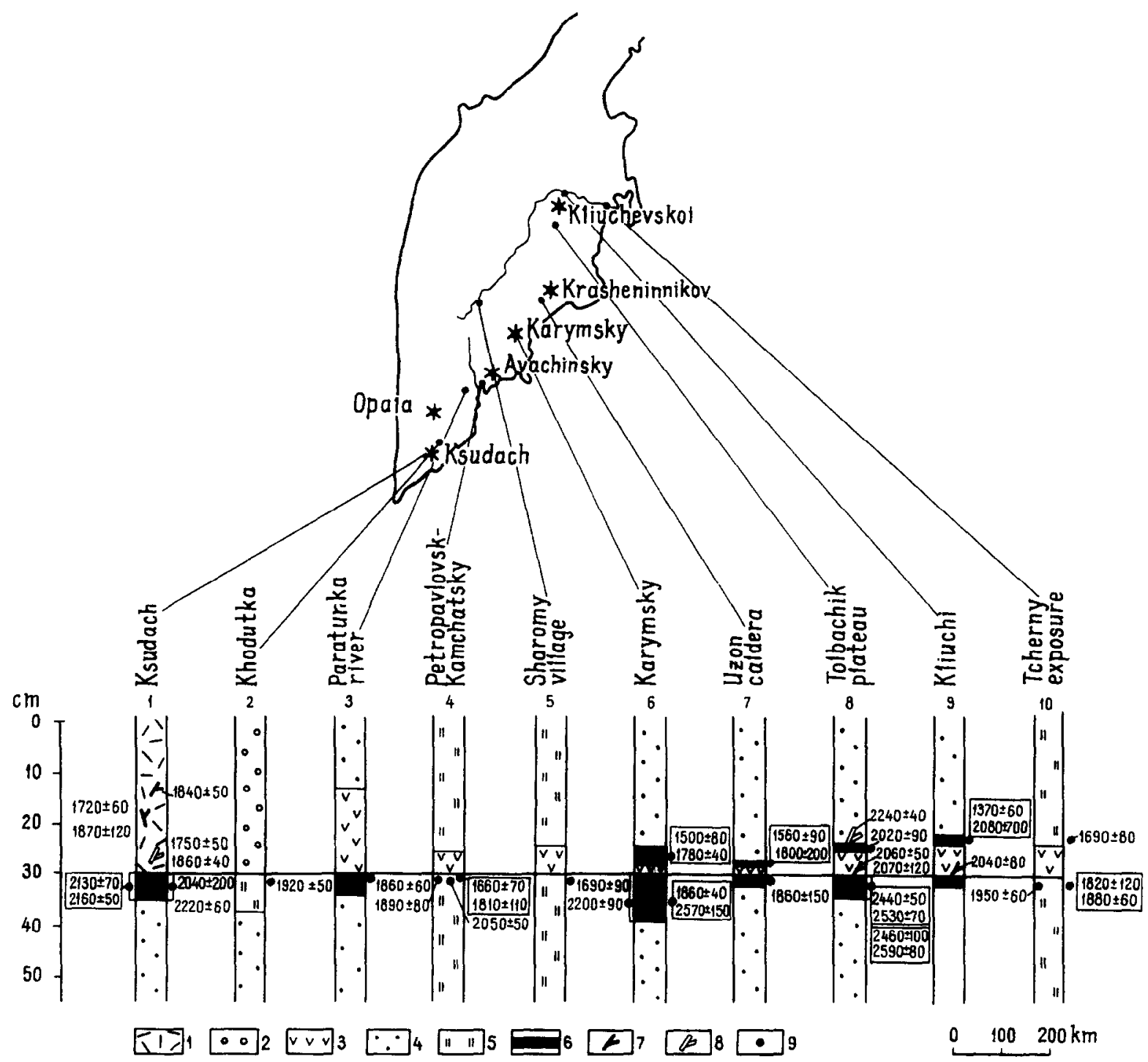

Fig. $11 .{ }^{14} \mathrm{C}$ dates for $\mathrm{KS}$, eruption deposits. $I=$ pyroclastic-flow deposits; $2=$ pumice lapilli; $3=$ coarse and fine ash; $4=$ deposits of soil-pyroclastic sequence; $5=$ peat; $6=$ buried soils; $7=$ charcoal; $8=$ wood; $9=$ position of samples dated. In the boxes are dates for successive alkaline extracts from the same soil sample. 
both the eruptions of Krakatau in $1883(3,800,000$ $\mathrm{km}^{2}$; Simkin and Fiske, 1983) and Quizapu, in Chile, in $1932\left(5,000,000 \mathrm{~km}^{2}\right.$; Casertano, 1965 ; Hildreth and Drake, 1992). If we assume that ash from the $\mathrm{KS}_{1}$ eruption fell in an area of $2,000,000$ or $3,000,000$ $\mathrm{km}^{2}$, then the total volume of tephra was at least $14-15 \mathrm{~km}^{3}$. Since at the distal edges of the surge deposits, it is difficult to discriminate tephra-fall from pyroclastic-surge deposits, the latter are included in the volume of tephra fall.

Pyroclastic flows of the $\mathrm{KS}_{1}$ enuption were also the most voluminous at Ksudach in the Holocene. The reconstruction has shown that they covered roughly $200 \mathrm{~km}^{2}$ with a volume of $3 \mathrm{~km}^{3}$ (the mean thickness of deposits was $15 \mathrm{~m}$ ) outside the caldera. We propose also that no less than $1 \mathrm{~km}^{3}$ of pyroclastic-flow deposits was deposited inside the $19-\mathrm{km}^{2}$ caldera with a mean thickness of about $50 \mathrm{~m}$. Then, we can estimate the total volume of pyroclastic-flow deposits to be about $4 \mathrm{~km}^{3}$.

Thus, the total volume of eruption products may have been of the order of $18-19 \mathrm{~km}^{3}$ or about $8 \mathrm{~km}^{3}$ DRE (calculated for dense rock at $2.3-2.4 \mathrm{~g} / \mathrm{cm}^{3}$, and pumiceous material at $1-1.1 \mathrm{~g} / \mathrm{cm}^{3}$ ). This value is in good agreement with the volume of the cavity of caldera $\mathrm{V}\left(6.5-7 \mathrm{~km}^{3}\right)$.

\section{The course of the eruption}

The $\mathrm{KS}_{1}$ eruption produced great amounts of tephra (Table 4). The course of the eruption has been reconstructed from the sequence of deposits (Fig. 10). The eruption began as phreatomagmatic with the formation of typical pyroclastic base surges. It is worth noting that the $\mathrm{KS}_{1}$ eruption began with the ejection of juvenile material whereas some other eruptions from Ksudach $\left(\mathrm{KS}_{2}, \mathrm{KS}_{3}\right)$ began with violent explosions, destroying substratum and forming a layer of explosion breccia. Then the explosive process became rhythmic (cyclic). At least four cycles are recognized. Each cycle began with tephra falls and finished with pyroclastic-flow emplacement. In the course of the $\mathrm{KS}_{1}$ eruption the proportion of juvenile material remained extremely high: lithics occur only in pyroclastic-flow deposits.

The height of the eruptive column was determined to be $23 \mathrm{~km}$ (Bursik et al., 1993). Further refinement has yielded column heights in the range of $22-30$ $\mathrm{km}$ (M. Bursik, pers. commun.). The ash-fall axis was directed to the north along the valley of the Kamchatka River (Fig. 2). The axis was shifted somewhat eastward at the beginning (yellow ash) and westward at the end (grey ash) of the eruption. The isopach pattern shows that at the latitude of the Kliuchevskoi volcano group and Shiveluch the ash cloud axis turned eastward to the ocean, which appears to have resulted from changing wind directions.

Pyroclastic flows moved down all flanks of the volcano except in the southern sector, where the high rims of the older calderas screened them.

Immediately after the caldera formed, a small extrusive dome (Fig. 4) grew inside it. According to bathymetric data reported by S.M. Fazlullin (pers. commun.) an analogous dome seems to exist at the bottom of Kliuchevoe lake, which has filled the caldera depression.

\section{Post-caldera activity}

In a short period of time (no more than 100 years) the Shtyubel stratovolcano started to form within the caldera (Braitseva et al., 1994). Its products are basaltic andesite and andesite with $\mathrm{SiO}_{2}$ in the range 54-62\% (Fig. 10). Threc large explosive eruptions occurred from the Shtyubel stratovolcano: 1000$1100 \mathrm{yr}$ B.P. $\left(\mathrm{KSh}_{1}\right), 300 \mathrm{yr}$ B.P. $\left(\mathrm{KSh}_{2}\right)$ and in $1907\left(\mathrm{KSh}_{3}\right)$. The volumes of tephra enupted were,

Table 4

Characteristics of caldera-forming enuption $\mathrm{KS}_{1}$, Ksudach, caldera $\mathrm{V}$

\begin{tabular}{lllllll}
$\begin{array}{l}\text { Volume of } \\
\text { fall deposits } \\
\left(\mathrm{km}^{3}\right)\end{array}$ & $\begin{array}{l}\text { Volume of pyroclastic- } \\
\text { flow deposits } \\
\left(\mathrm{km}^{3}\right)\end{array}$ & $\begin{array}{l}\text { Total } \\
\text { volume } \\
\left(\mathrm{km}^{3}\right)\end{array}$ & $\begin{array}{l}\text { Volume recalculated } \\
\text { DRE } \\
\left(\mathrm{km}^{3}\right)\end{array}$ & $\begin{array}{l}\text { Height of } \\
\text { eruptive column } \\
(\mathrm{km})\end{array}$ & $\begin{array}{l}\text { Caldera } \\
\text { size } \\
(\mathrm{km})\end{array}$ & $\begin{array}{l}\text { Volume of } \\
\text { caldera cavity } \\
\left(\mathrm{km}^{3}\right)\end{array}$ \\
\hline $14-15$ & 4 & $18-19$ & 8 & 23 & $4 \times 6.5$ & $6.5-7$ \\
\hline
\end{tabular}


respectively, $1,0.4-0.5$ and $1.5-2 \mathrm{~km}^{3}$, and the heights of eruptive columns were $>15 \mathrm{~km},>10$ $\mathrm{km}$ and as high as $22 \mathrm{~km}$ (Bursik et al., 1993). At Ksudach, tephra layers from the $\mathrm{KSh}_{1}$ and $\mathrm{KSh}_{3}$ eruptions are distinctly zoned: the lower portions of each contain black basaltic andesite lapilli or coarse ash with $54-56 \% \mathrm{SiO}_{2}$, and the upper portions consist of light-colored pumice bombs and lapilli with $56-66 \% \mathrm{SiO}_{2}$. Banded varieties are abundant among pumice bombs of both eruptions. The $\mathrm{SiO}_{2}$ contents of adjacent bands differ by 6-8\% (Volynets, 1979a).

These compositional variations in the Ksudach enupted products suggest that the $\mathrm{KS}_{1}$ eruption may have been triggered by injection of hot mafic magma into a cooler silicic magma reservoir (Sparks and Sigurdsson, 1977; Volynets, 1979b). During the KS, eruption, magma was ejected from the uppermost, silicic portion of the reservoir. More mafic magma came to the surface later, during formation of the Shtyubel Cone (Fig. 10).

\section{Environmental impact}

The volume of erupted products for $\mathrm{KS}_{1}(18-19$ $\mathrm{km}^{3}$ ) exceeds that for any eruption of our era not only in Kamchatka, but also within the $4000-\mathrm{km}$ northwestern portion of the Ring of Fire, including Japan, the Kurile Islands and Kamchatka. Such a volume of erupted material ranks the $K S_{1}$ eruption with the well-known eruptions of Krakatau in 1883 (17-21 $\mathrm{km}^{3}$; Self and Rampino, 1981) and Katmai/Novarupta in $1912\left(17 \mathrm{~km}^{3}\right.$ of tephra; Fierstein and Hildreth, 1992). The height of the $\mathrm{KS}_{1}$ eruptive column $(22-30 \mathrm{~km})$ is comparable with that of Novarupta $(17-26 \mathrm{~km})$. The $\mathrm{KS}_{1}$ eruption may therefore have greatly affected the atmosphere as did the Krakatau and Katmai eruptions, and the Ksudach eruption of 1907 (Hulten, 1924; Lamb, 1970).

The Ksudach 1907 eruption produced a moderate acidity peak in the Greenland ice (Hammer et al., 1980). The volume of the $\mathrm{KS}_{\text {, }}$ eruption exceeds by an order of magnitude that of the 1907 eruption from Shtyubel Cone and is comparable with those of the Krakatau and Katmai eruptions, which produced distinct acidity peaks in the Greenland ice. Based on this observation, the $\mathrm{KS}_{1}$ eruption should also be represented by an acidity peak. Unfortunately, no data are available in the Crete and Camp Century cores for the interval A.D. 147-317 when the KS, eruption must have occurred (Hammer et al., 1980). Data for the GISP2 ice core (Zielinski et al., 1994) suggest that five peaks in $\mathrm{SO}_{4}^{2-}$ concentration (A.D. $152,161,181,264$ and 267) fall into this interval. We think it more likely that either the A.D. 264 or the A.D. 267 peak was caused by the $\mathrm{KS}_{1}$ eruption as they are closer to average age A.D. 236.

The voluminous $K S_{1}$ eruption was probably an ecological catastrophe for Kamchatka, due to dispersal of tephra mainly along the peninsula. The minimum area of total devastation coinciding with pyroclastic-flow deposits and heavy tephra fallout is about $400-500 \mathrm{~km}^{2}$ (following the $40-\mathrm{cm}$ isopach of Fig. 2). Vegetation was also adversely affected over an additional area of about $12,000 \mathrm{~km}^{2}$ where ash thickness was $5-40 \mathrm{~cm}$. Only outside the $5-\mathrm{cm}$ isopach might the vegetation have benefited from the ash as a source of useful trace elements.

\section{Conclusions}

(1) The latest caldera-forming eruption from Ksudach $\left(K_{1}\right)$, which occurred about A.D. 240, was the greatest eruption of our era in the Kurile-Kamchatka region: the volume of pyroclastics was $18-19 \mathrm{~km}^{3}$, of which $14-15 \mathrm{~km}^{3}$ was from tephra falls. The height of the eruptive column reached $22-30 \mathrm{~km}$. As a result of this eruption, a collapse caldera (caldera V) with a size of $4 \times 6.5 \mathrm{~km}$ and a cavity volume of $6.5-7 \mathrm{~km}^{3}$ was formed.

(2) The eruption began as phreatomagmatic with the formation of pyroclastic surges. Later the process became rhythmic: repeated tephra falls were followed by the formation of pyroclastic flows extending outward for $20 \mathrm{~km}$. Tephra was dispersed northward to a distance of more than $1000 \mathrm{~km}$. The composition of erupted products was rhyodacite, remaining unchanged during the eruption. Only in the post-caldera stage, during the formation of Shtyubel Cone within the caldera was more mafic material supplied to the surface.

(3) The injection of more mafic melt into a felsic magma chamber and the mixing of magmas with 
different compositions may have been the triggering mechanism for the eruption.

(4) The characteristics of the $\mathrm{KS}_{\text {, }}$ eruption are comparable with those of the 1883 Krakatau eruption. The eruption may have affected the climate and produced an acidity peak in the Greenland ice.

\section{Acknowledgements}

The research described in this paper was supported by the Grant No. 94-05-16856 from the Russian Fundamental Science Foundation and by Grant No. RMG000 from the International Science Foundation. We thank Drs. Marcus Bursik, James Luhr and Donald Swanson for thorough reviewing the manuscript and valuable comments.

\section{References}

Braitseva, O.A., Melekestsev, I.V., Flerov, G.B., Ponomareva, V.V., Sulerzhitsky, L.D. and Litasova, S.N., 1984. Holocene volcanism of the Tolbachik regional zone of cinder cones. In: S.A. Fedotov (Editor), Great Tolbachik Fissure Eruption, Kamchatka, 1975-1976. Nauka, Moscow, pp. 177-209 (in Russian).

Braitseva, O.A., Sulerzhitsky, L.D., Litasova, S.N. and Grebzdy, E.I., 1988. Radiocarbon dating of soils and pyroclastic deposits in Kliuchevskoi group of volcanoes. Volcanol. Seismol., 6: $317-325$.

Braitseva, O.A., Florenskii, I.V., Ponomareva, V.V. and Litasova, S.N., 1989a. The history of the activity of Kikhpinych volcano in the Holocene. Volcanol. Seismol., 7(6): 845-872.

Braitseva, O.A., Kirianov, V.Yu. and Sulerzhitsky, L.D., 1989 . Marker intercalations of Holocene tephra in the Eastern volcanic zone of Kamchatka. Volcanol. Seismol., 7(5): 785-814.

Braitseva, O.A., Melekestsev, I.V., Bogoyavlenskaya, G.E. and Maksimov, A.P., 1991. Bezymianny Volcano: the history of formation and activity dynamics. Volcanol. Seismol., 12(2): $165-194$.

Braitseva, O.A., Melekestsev, I.V., Ponomareva, V.V., Kirianov, V.Yu., Litasova, S.N. and Sulerzhitsky, L.D., 1992. Tephra of the largest prehistoric Holocene volcanic eruptions in Kamchatka. Quat. Int., 13-14: 177-180.

Braitseva, O.A., Sulerzhitsky, L.D., Litasova, S.N., Melekestsev, I.V. and Ponomareva, V.V., 1993. Radiocarbon dating and tephrochronology in Kamchatka. Radiocarbon, 35(3): $463-$ 476.

Braitseva, O.A., Melekestsev, I.V., Ponomareva, V.V., Sulerzhitsky, L.D. and Litasova, S.N., 1994. The ages of active volcanoes in the Kurile-Kamchatka region. Volcanol. Seismol., 16(4-5): $341-370$.

Brazier, S., Sparks, R.S.J., Carey, S.N., Sigurdsson, H. and West- gate, J.A., 1983. Bimodal grain size distribution and secondary thickening in air-fall ash layers. Nature, 301: 115-119.

Bursik, M.I., Melekestsev, I.V. and Braitseva, O.A., 1993. Most recent fall deposits of Ksudach volcano, Kamchatka, Russia. Geophys. Res. Lett., 20(17): 1815-1818.

Casertano, L., 1965. Chilean Continent. Catalogue of the Active Volcanoes of the World Including Solfatara Fields. Pt. XV, Napoly, 56 pp.

Dikov, N.N., 1969. Ancient Camp-fires of Kamchatka and Chukotka. Magadan Publ. House, Magadan, 252 pp. (in Russian).

Felitsyn, S.B. and Kirianov, V.Yu., 1990. Areal variability of tephra composition as indicated by bulk silicate analysis data. Volcanol. Seismol., $9(1)$ : 1-20.

Felitsyn, S.B., Vaganov, P.A. and Kirianov, V.Yu., 1991. Trace element distribution in Kamchatkan ashes from instrumental neutron activation analysis. Volcanol. Seismol., 12(2): 195213.

Fierstein, J. and Hildreth, W., 1992. The Plinian eruption of 1912 at Novarupta, Katmai National Park, Alaska. Bull. Volcanol., 54: 646-684.

Geptner, A.P. and Ponomareva, V.V., 1979. Application of mineralogical analysis to correlate ashes of Shiveluch volcano. Bull. Volcanol. Stancii, 56: 126-130 (in Russian).

Gill, J., 1981. Orogenic Andesites and Plate Tectonics. Springer, Berlin, $390 \mathrm{pp}$.

Gushchenko, I.I., 1965. Ashes from North Kamchatka and Conditions of their Formation. Nauka, Moscow, 144 pp. (in Russian).

Hammer, C.U., Clausen, H.B. and Dansgaard, W., 1980. Greenland ice sheet evidence of postglacial volcanism and its climatic impact. Nature, 288: 230-235.

Hildreth, W. and Drake, R.E., 1992. Volcan Quizapu. Chilean Andes. Bull. Volcanol., 54: 93-125.

Hulten, E., 1924. Eruption of a Kamchatka volcano in 1907 and its atmospheric consequences. Geol. Foeren. Foerh., 46: 407417.

Kirianov, V.Yu., 1983. Gravitational eolian differentiation of ashes from Shiveluch volcano (Kamchatka). Volcanol. Seismol., 6: 30-39 (in Russian).

Kirianov, V.Yu. and Solovyova, N.A., 1991. Lateral variations in ash composition due to eolian differentiation. Volcanol. Seismol., 12(4): $431-442$.

Kirianov, V.Yu., Zharinov, S.E. and Perepelov, A.B., 1990. On possible geochemical difference in marker volcanic ashes of Eastern Kamchatka. Volcanol. Seismol., 9(2); 194-199.

Kirsanova, T.P. and Melekestsev, I.V., 1988. On the origin and age of Khodutka thermal springs. Volcanol. Seismol., 6: 711725 .

Lamb, H.H., 1970. Volcanic dust in the atmosphere; with a chronology and assessment of its meteorological significance. Philos. Trans. R. Soc. London, Ser. A, 266: 425-533.

Markhinin, E.K., Pugach, V.V. and Markhinina, S.N., 1962. On natural magnetization of ash layers in the region of the Kliuchevskoi volcano group. Bull. Volcanol. Stancii, 33: 47-57 (in Russian).

Melekestsev, I.V. and Kirianov, V.Yu., 1988. When will Avacha volcano in Kamchatka erupt? Volcanol. Seismol., 6(6): 943952. 
Melekestsev, I.V. and Sulerzhitsky, L.D., 1990. Ksudach volcano (Kamchatka) over the last ten thousand years. Volcanol. Seismol., $9(4): 537-556$.

Melekestsev, I.V., Braitseva, O.A. and Ponomareva, V.V., 1990. Holocene activity dynamics of Mutnovskii and Gorelyi volcanoes and the volcanic risk for adjacent areas (as indicated by tephrochronology studies). Volcanol. Seismol., 9(3): 337-362.

Menyailov, A.A., 1955. Shiveluch volcano: its geologic structure, composition, and eruptions. Proc. Lab. Volcanol. AN SSSR 9, 264 pp. (in Russian).

Moore, J.G. and Peck, D.L., 1962. Accretionary lapilli in volcanic rocks of the westem continental U.S. J. Geol., 70: 182-193.

Piyp, B.I., 1948. A new eruptive state of Shiveluch volcano from the end of 1944 to May, 1945, and information on its geologic structure and past eruptions. Bull. Volcanol. Obs. Kamchatka, 14: 38-51 (in Russian).

Self, S. and Rampino, M.R., 1981. The 1883 eruption of Krakatau. Nature, 294: 699-704.

Selyangin, O.B., 1990. Geologic structure and evolution of the calderas of Ksudach volcano. Volcanol. Seismol., $9(5)$ : 690713.

Simkin, T. and Fiske, R.S., 1983. Krakatau 1883. The Volcanic
Eruption and its Effects. Smithsonian Institution Press, Washington, $464 \mathrm{pp}$.

Sparks, S.R.J. and Sigurdsson, H., 1977. Magma mixing: a mechanism for triggering acid explosive eruptions. Nature, 267: 315-318.

Stuiver, M. and Reimer, P.J., 1993. Extended ${ }^{14} \mathrm{C}$ data base and revised CALIB $3.0{ }^{14} \mathrm{C}$ age calibration program. Radiocarbon, 35: 215-230.

Volynets, O.N., 1979a. Heteroxitic lavas and pumices (on the problem of magma mixing). In: V.S. Sobolev (Editor), Problems of Deep Magmatism. Nauka, Moscow, 181-197 pp. (in Russian).

Volynets, O.N., 1979b. Mixed lavas. Relationship of the melts forming these lavas. Bull. Volcanol., 42(1-4): 233-242.

Walker, G.P.L. and Croasdale, R., 1972. Characteristics of some basaltic pyroclastics. Bull. Volcanol., 32(2): 303-315.

Zielinski, G.A., Mayewski, P.A., Meekcr, L.D., Whitlow, S., Twickler, M.S., Morrison, M., Meese, D.A., Gow, A.J. and Alley, R.B., 1994. Record of volcanism since 7000 B.C. from the GISP2 Greenland ice core and implications for the volcano-climate system. Science, 264: 948-952. 